\title{
The use of a Detrended Cross-Correlation Analysis on returns from agricultural commodities in the subprime crisis
}

Luiza Lonardoni Paulino Schiavon ${ }^{1}$, São Paulo State University, Production Engineering Department, Bauru, São Paulo, Brazil

Antônio Fernando Crepaldi² ${ }^{2}$ São Paulo State University, Production Engineering Department, Bauru, São Paulo, Brazil

\section{RESUMO}

Objetivo: Compreender a dinâmica do mercado das commodites agrícolas e extrair o prenúncio de uma possível crise econômica, além de ajudar produtores agrícolas a balancear sua carteira de produtos, diversificando suas mercadorias e diminuindo os riscos.

Referencial Teórico: Os preços das commodities agrícolas vem sofrendo mudanças significativas desde 2002; embora houve um crescimento da demanda, problemas climáticos afetaram negativamente a oferta, resultando no aumento do preço. Com a crise financeira mundial de 2008, houve a redução do crédito internacional e o aumento do dólar no Brasil.

Metodologia: Foram utilizados os métodos Detrended Cross-Correlation Analysis e Detrended Fluctuation Analysis afim de entender o comportamento das correlações cruzadas do preço de cinco commodities do agronegócio brasileiro (algodão, açúcar, café, milho e soja) para os períodos anterior, durante e posterior à crise do subprime.

Resultados: Ambos os métodos evidenciaram uma mudança significativa no comportamento das séries no período de crise, se comparado às suas vizinhanças temporais.

Implicações: Observou-se que a crise provoca mudanças na estrutura de correlação dos retornos das commodities analisadas. Essa mudança implica em alterações de uma possível carteira de produtos a fim de minimizar riscos.

Originalidade: Foi calculado e analisado o comportamento de correlação não-linear de longo prazo das séries temporais de retorno das principais commodities agrícolas no período da crise do subprime e suas vizinhanças temporais, permitindo constatar diversas mudanças na estrutura de correlação dos produtos, devido ao processo de crise.

Palavras-Chaves: Crise Financeira do Subprime; Commodities Agrícolas; Detrended Fluctuation Analysis; Detrended CrossCorrelation Analysis.

\section{ABSTRACT}

Purpose: To understand the dynamics of the agricultural commodities market and predict a possible economic crisis, in addition to helping agricultural producers balance their product portfolio, diversifying their goods and reducing risks.

Theoretical framework: Prices of agricultural commodities have changed significantly since 2002; although had been an increase in demand, where weather problems negatively affected supply, resulting in price increases. With the global financial crisis of 2008, there was a reduction in international credit and an increase in the US dollar against the Brazilian Real.

Design/Methodology/Approach: Detrended Cross-Correlation Analysis and Detrended Fluctuation Analysis methods were used to understand the behavior of the cross correlations of the price of five Brazilian agribusiness commodities (cotton, sugar, coffee, corn and soybeans) for the previous periods, during and after the subprime crisis.

Findings: Both methods showed a significant change in the behavior of the series in the period of crisis, when compared to their temporal neighborhoods.

Research, Practical \& Social Implications: It was found that the crisis changed the structure of the correlation of the returns on the commodities analyzed. This change implies alterations to a possible product portfolio in order to minimize risks.

Originality/Value: The long-term nonlinear correlation behavior was calculated and analyzed on the temporal series for the return on the main agricultural commodities in the period of the subprime crisis and its temporal neighborhoods were calculated and analyzed, allowing several changes to be found in the product correlation structure, due to the crisis process.

Keywords: Subprime Financial Crisis; Agricultural Commodities; Detrended Fluctuation Analysis; Detrended Cross-Correlation Analysis.

1. Av. Eng. Luís Edmundo Carrijo Coube, 14-01 - Nucleo Res. Pres. Geisel, Bauru - SP, 17033-360, lpschiavon@gmail.com; https://orcid.org/0000-0002-2816-2728; $\quad 2 . \quad$ antonio.f.crepaldi@unesp.br; https://orcid.org/0000-0002-9090-1835.

SCHIAVON, L.L.P.; CREPALDI, A.F. The use of a Detrended Cross-Correlation Analysis on returns from agricultural commodities in the subprime crisis. GEPROS. Gestão da Produção, Operações e Sistemas, v.16, no 3, p. 119 - 137, 2021. 


\section{INTRODUCTION}

The prices of agricultural commodities have been undergoing relevant changes since 2002, when there was significant growth in emerging countries. In this period, there was also a significant increase in prices due to the strong growth in demand and climate problems that negatively affected the supply. In this context, countries that had a high participation in commodities were able to benefit from this increase in prices, improving their current accounts, reducing foreign debt and creating financial reserves. However, this growth was interrupted by the global financial crisis of 2008 (ABE, 2011).

The global financial crisis began with the American subprime market crisis that caused the interruption of the growth of world economies and, consequently, there was a retraction of exports (SILVA FILHO, 2009). According to Vasquez (2008) cited by Jale (2015), "subprime is a high-risk housing credit aimed at a slice of the population with lower incomes and a more unstable economic situation". Therefore, it is a line of credit with a high risk of default because it deals with low-income people (CARVALHO, 2008).

Brazil has great economic dependence on the agricultural sector, given that $23.5 \%$ of Brazilian GDP was generated by agribusiness in 2017. In 2016, the soybean complex accounted for $35.6 \%$ of the total value of Brazilian agricultural and livestock exports. Added to this, there is a strong participation of Brazil, from 2007 to 2016, in the international trade of the following products: soybean complex (29\% participation), beef (16\% participation), corn (15\% participation), coffee (20\% participation), sugar (45\% participation), chicken meat (35\% participation) and cotton (12\% participation). Thus, considering only agricultural commodities, the products analyzed in this study (corn, soybeans, sugar, coffee and cotton) are of paramount importance to the Brazilian economy (MINISTRY OF AGRICULTURE, 2017).

In this sense, this work proposed to perform an analysis of the correlation spectrum of agricultural commodity price returns by means of Detrended Fluctuation Analysis - DFA and Detrended Cross-Correlation Analysis - DCCA, thus contributing to the understanding of the market dynamics of these products and the extraction of a forewarning of a possible economic crisis. In addition, this work also helps agricultural producers to balance their product portfolio, diversifying their commodities and reducing risks. 


\section{THEORETICAL FOUNDATION}

\subsection{Agricultural commodities}

Commodities is an English term meaning merchandise and is used in commercial transactions of primary products on commodity exchanges. In addition, commodities that designate products with a small degree of industrialization, in a raw state, produced on a large scale, by different producers, do not present differentiation and have a low added value (JALE, 2015).

According to German (2005), agricultural commodity prices are seasonal and highly volatile due to factors related to weather, degradation of agricultural products and storage. In addition, there are issues related to harvest, off-season, protection strategies and custom barriers in the development of international markets that affect the random behavior of prices, making them difficult to describe and predict.

\subsection{Time series}

According to Morettin and Toloi (2004), a time series is a set of observations ordered in time, which can be symbolized by equation 1 :

$$
Y=F(t)
$$

Where $Y_{1}, Y_{2}, Y_{3} \ldots, Y_{n}$ are the values of variable $Y$ at time $t_{1}, t_{2}, t_{3}, \ldots, t_{n}$.

According to Ehlers (2007), the main objectives in the analysis of a time series are: description, that is, to describe the properties of the series, patterns, the existence of seasonal or structural variation; control, to verify manufacturing processes, since the series measures the "quality" of a process; explanation of the variation in a series by means of the variation in another series; and prediction of future values based on the past.

According to Silva (2011), one can cite as examples of time series the murder rate per inhabitant, the daily values of average temperature, the values of electricity consumption and the daily index of the São Paulo Stock Exchange. 


\subsection{Análise da Flutuação Deteriorada (DFA)}

According to Siqueira Junior et al. (2010), the Detrended Fluctuation Analysis (DFA) is a method used for quantification of correlations in a time series introduced by Peng et al. (1994) and successfully applied to detect long-range correlations in DNA sequences. In addition, this method was used by Peng et al. (1995) in non-stationary time series of physiological sequences, in meteorological data by Koscielny-Bunde et al. (1998) and in financial time series by Crepaldi (2007).

The method can be summarized in the following steps (MARINHO et al., 2013):

Starting from the original time series $x(i), i=1,2, \ldots, N$, the integrated time series $y(i)$, as in equation 2 , is defined:

$$
y(j)=\sum_{i=1}^{j} x(i)
$$

The integrated time series of size $\mathrm{N}$ is divided into $n=N / l$ boxes, without intersection. In each box containing ${ }^{l}$ data, a trend line is constructed using the least squares method.

The trend path is defined as the difference between the integrated series, $y(j)$ and the values estimated from the method of least squares $Y(j)$ for each box.

The standard deviation of this fluctuation is calculated using equation 3 :

$$
F_{D F A}(l)=\sqrt{\frac{1}{N} \sum_{k=0}^{n-1}\left[\sum_{j=k l+1}^{(k+1) l}[y(j)-Y(j)]^{2}\right]}
$$

The calculation of the equation is repeated for different values of $l$, and thus the relationship between $F_{D F A}(l)$ and ${ }^{l}$ is established. The angular coefficient of the least squares line in to fit the points established between $F_{D F A}(l)$ and ${ }^{l}$, both in logarithmic scale, equal the value of the DFA. 


\subsection{Detrended Cross-Correlation Analysis (DCCA)}

Detrended Cross-Correlation Analysis (DCCA) was introduced by Podobnik (2008) for the quantification of long-range cross-correlations between time series. This method represents a generalization of DFA and is designed to analyze power law cross-correlations between two nonstationary time series taken simultaneously. In addition, DCCA has already been applied in other studies, such as in the stock market by Wang et al. (2013), in road transportation by Kristoufek (2014), in medicine by Podobnik et al (2011), in biological signals by Ursulean and Lazar (2009), in financial series by Podobnik (2008) and by Siqueira Junior et al. (2008).

To apply the method, we proceed as follows (PODOBNIK, 2008):

One integrates the two series that one wants to analyze, according to equation 4:

$$
\hat{x}(j)=\sum_{i=1}^{j} x(i) \quad \text { and } \quad \hat{z}(j)=\sum_{i=1}^{j} z(i)
$$

The integrated series ${ }^{\hat{x}}$ and ${ }^{\hat{z}}$ are divided into $\mathrm{n}$ bins of size $l=N / n$.

Trend lines are constructed using the method of least squares. The series without trend are obtained from the differences $x(j)-\hat{x}(j) \mathrm{e}^{z(j)-\hat{z}(j)}$ for each bin.

We calculate the covariance between the series for the different box sizes, according to equation 5:

$$
F_{D C C A}^{2}(l)=\sqrt{\frac{1}{N} \sum_{k=0}^{n-1}\left[\sum_{j=k l+1}^{(k+1) l}[x(j)-\hat{x}(j)][z(j)-\hat{z}(j)]\right]}
$$

It turns out that the $F_{D C C A}$ resumes the calculation of $F_{D F A}$ for values of $x=z$. As observed for DFA, in DCCA the values of $F_{D C C A}(l)$ scale as $F_{D C C A}(l)_{\sim} l^{\gamma}$. 
One of the advantages of ACD over other methods of cross-correlation detection, such as Pearson's correlation coefficient, is the possibility of identifying and measuring correlation between two signals on different time scales (SILVA FILHO, 2009).

In both cases, DFA and DCCA, values of the growth rate of the straight line, $\gamma$, represent the trend in the behavior of the series, in the case of DFA, and between series, in the case of DCCA. Thus, for $\gamma=0.5$ means that the current values have no correlation with previous data. If $\gamma>0.5$ the series is said to be persistent, that is, large (or small) fluctuations are followed by fluctuations that behave in the same direction and intensity, on average. And finally, $\gamma<0.5$ the series is antipersistent, so large (or small) fluctuations are likely followed by fluctuations of opposite behavior (MARINHO et al., 2013).

\section{METHODOLOGICAL PROCEDURES}

\subsection{Object of study}

This study used time series of prices, with daily frequency, of five agricultural commodities: cotton, sugar, coffee, corn, and soybeans. The motivation to analyze the agricultural commodity series is due to the importance of this type of good for the Brazilian economy, since agribusiness represented almost $1 / 4$ of the Brazilian GDP in 2017. Also, specifically, Brazil is a large producer of these agricultural commodities globally - 1st producer of sugar, coffee and soybeans; 3rd largest producer of corn and 5th largest producer of cotton (EMBRAPA SOJA, 2019; GUTH, 2019; SEVERINO, 2019; SHAHBANDEH, 2019; UNITED STATES DEPARTMENT OF AGRICULTURE (USDA), 2019).

\subsection{Data collection procedures}

The dataset used to refer to the daily closing prices of the five agricultural commodities came from the official website of the School of Agriculture "Luiz de Queiroz" (ESALQ), a unit of the University of São Paulo (USP). The data was extracted from the price history on April 18, 2018 and treated in Excel (XLS). With the database ready, an algorithm was created in MatLab R2015a to implement the DFA and DCCA methods.

For the present study, three-time intervals were considered: the period before the crisis (08/02/2004 to $09 / 14 / 2008)$, during the crisis $(09 / 15 / 2008$ to $12 / 31 / 2009)$ and after the 
subprime crisis $(01 / 01 / 2010$ to $04 / 18 / 2018)$. The date that determines the initial period of the subprime crisis corresponds to the announcement of the bankruptcy of the fourth largest US bank, Lehman Brothers; and the end date is the beginning of 2010, the period already considered as post-crisis.

Commodities are traded, as of the ESALQ/BM\&FBOVESPA indicator, as follows (CEPEA, 2018):

- Cotton: traded from the indicator ESALQ / BM\&FBOVESPA by the daily closing price in cents per pound of feather $(0.453597 \mathrm{~kg})$. Product specification: Cotton lint type 41 , sheet 4 - strict low middling - (former type 6, fiber $30 / 32 \mathrm{~mm}$, no characteristics).

- Crystal Sugar: traded from the ESALQ/BM\&FBOVESPA indicator at the daily closing price of the $50 \mathrm{Kg}$ bag. Product specification: with minimum 99.7 degrees of polarization, maximum $0.10 \%$ moisture, most frequent ICUMSA color 130 - 180, maximum $0.07 \%$ ash, bagged in new polypropylene bags, intended for the domestic market. Region of reference: State of SP - divided into 6 regions: Piracicaba, Ribeirão Preto, Jaú, Assis, São José do Rio Preto and Araçatuba.

- Arabica coffee: traded based on the ESALQ/BM\&FBOVESPA indicator for the daily closing price of the $60 \mathrm{~kg}$ bag. Product specification: Arabica coffee type 6 , hard drink for better, well prepared, with up to 86 defects per 300 gram sample.

- Corn: traded based on the ESALQ/BM\&FBOVESPA indicator for the daily closing price of the $60 \mathrm{Kg}$ bag. Product specifications: Semi-hard yellow corn, type 2, with normal odor and appearance, in good condition, free of castor bean berries and other harmful seeds and live insects, hard or semi-hard, with moisture content of up to $14 \%$, maximum impurity content of $1 \%$ on the $3 \mathrm{~mm}$ sieve, maximum $6 \%$ of burnt or sprouted grains and free of moldy grains and up to $12 \%$ broken, broken or shocked grains.

- Soybeans: traded based on the ESALQ/BM\&FBOVESPA indicator at the daily closing price of the $60-\mathrm{kg}$ bag. Product specifications: bulk soybean, export type, according to Concex standard: up to $14 \%$ humidity, up to $2 \%$ impurities, and maximum limits of $8 \%$ for damaged grains (up to $5 \%$ of burned) and $30 \%$ of broken grains. Reference region: Paraná state, divided into five regions: Paranaguá, Ponta Grossa, North, West, and Southwest. 


\subsection{Data analysis procedures}

The paper used empirical research to obtain data on the correlations of agricultural commodity price returns, for which the Detrended Fluctuation Analysis - DFA and the Detrended Cross-Correlation Analysis - DCCA methods were used.

The returns were calculated from the prices using equation 6:

$$
r(t)=\ln \frac{p(t)}{p(t-1)}
$$

\section{RESULTS}

Figures 1 to 5 show the daily closing price of commodities from August 2, 2004 to April 18, 2018. The vertical lines in red indicate the periods before, during and after the subprime financial crisis.

Figure 1 - Time series of daily closing prices of cotton

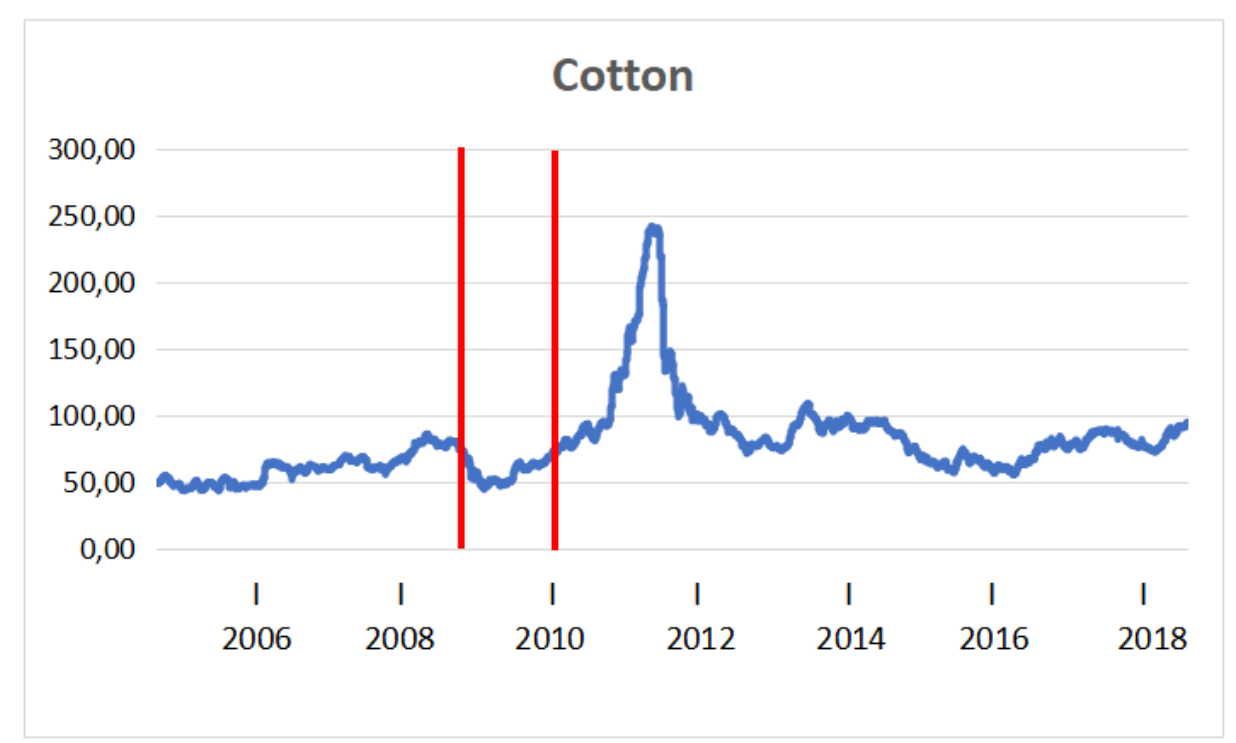

Source: Prepared by the author, 2020. 
The use of a Detrended Cross-Correlation Analysis on returns from agricultural commodities in the subprime crisis

Figure 2 - Time series of daily closing prices of sugar

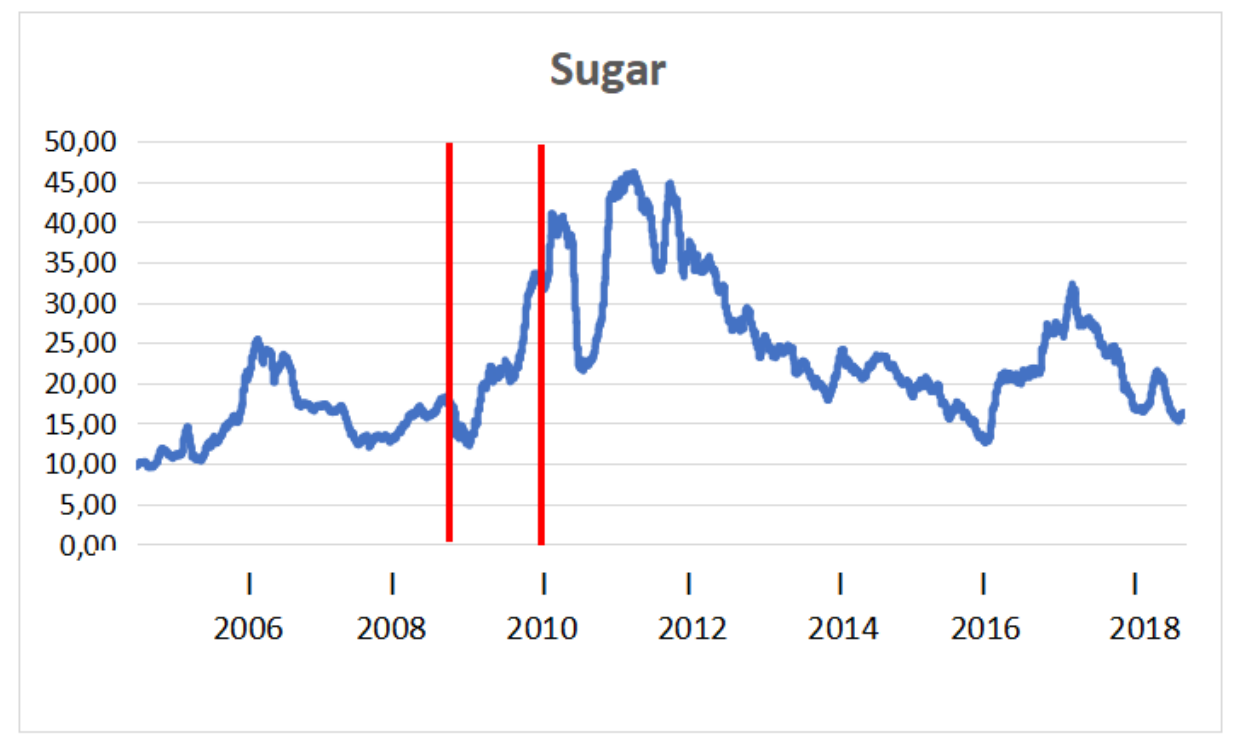

Source: Prepared by the author, 2020.

Figure 3 - Time series of daily closing prices of coffee

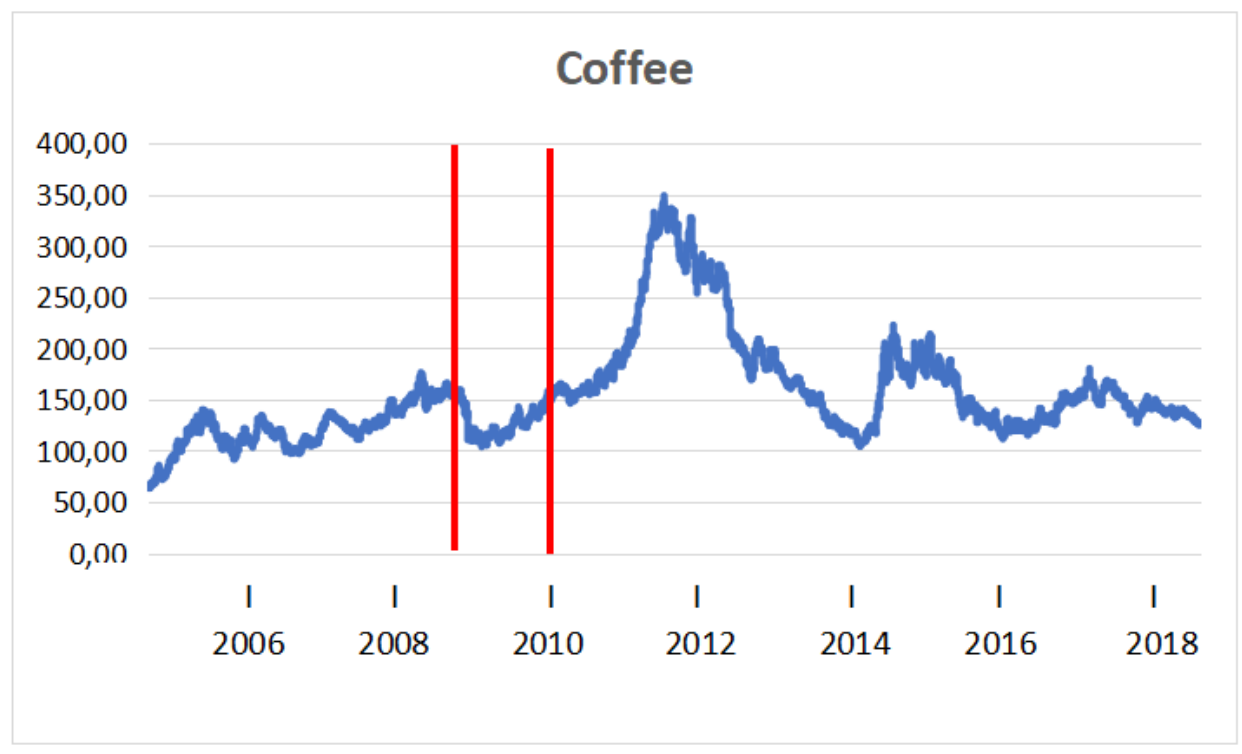

Source: Prepared by the author, 2020. 
Figure 4 - Time series of daily closing prices of corn

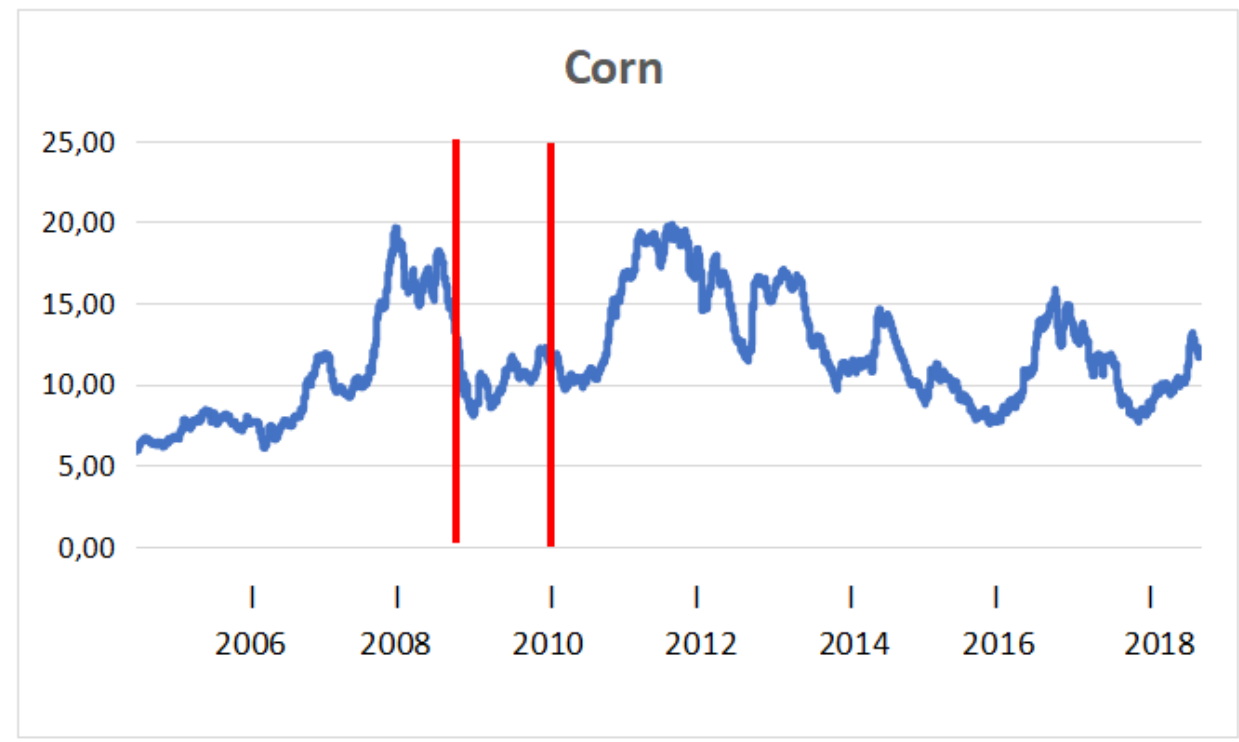

Source: Prepared by the author, 2020.

Figure 5 - Time series of daily closing prices of soybean

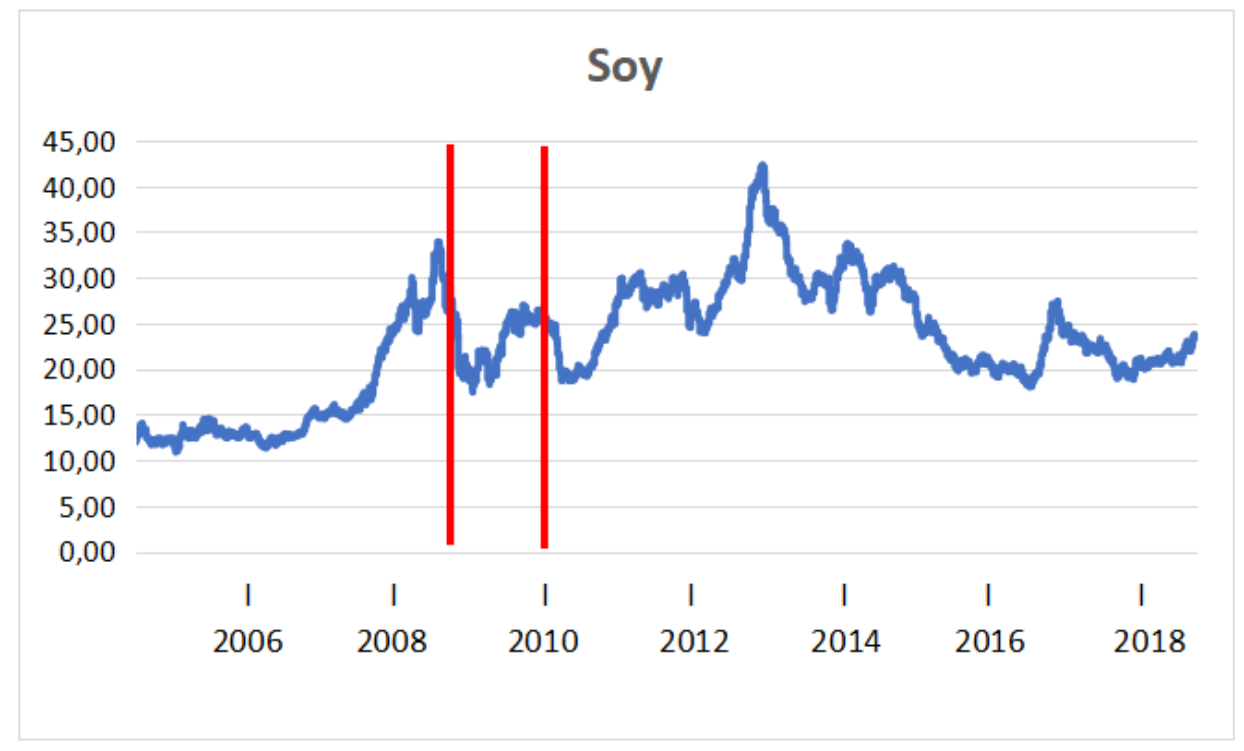

Source: Prepared by the author, 2020.

Analyzing Figures 1 to 5, it can be observed that in the period before the crisis, cotton and coffee maintained a stable price, while the price of corn and soybean were oscillating, after a substantial growth process. And the price of sugar was relatively stable after parabolic 
growth. During the subprime financial crisis, the price of all products, except for sugar, show a fall and subsequent increase, as a valley behavior, where at the end of the process the price is at a level close to that existing before the crisis. In the specific case of sugar, this valley behavior also occurs, however, with a smaller decline and a quick and consistent price resumption, in such a way that, at the end of the crisis, the price of sugar is at a level significantly higher than the price existing before the crisis. After the crisis, price instability is predominant in all products.

In the years following the crisis period, a growth in commodity prices is observed in the respective series presented. Cotton, sugar, coffee and corn reach their maximum value in the first seven months of 2011 (01/2011 to 07/2011), the peak of soybean prices is given a little later, in September 2012.

Comparing the average prices of the first seven months of 2011 with the first seven months of 2009 and the relative growth of these series, we notice that cotton, sugar and coffee had the highest growth in this period, $232 \%, 102 \%$ and $152 \%$, respectively. Notice also that these are the same products that presented the largest declines after this period. Table 1 shows the overall result of the DFA and DCCA methods.

Table 1 - Overall result of DFA and DCCA.

\begin{tabular}{c|c|c|c|c|c} 
& Cotton & Sugar & Coffee & Corn & Soy \\
\hline Cotton & $\mathbf{0 , 8 0 9}$ & 0,7876 & 0,8763 & 0,8041 & 0,8211 \\
\hline Sugar & & $\mathbf{0 , 7 9 5 6}$ & 0,8795 & 0,7729 & 0,8061 \\
\hline Coffee & & & $\mathbf{0 , 7 5 4 6}$ & 0,8302 & 0,8448 \\
\hline Corn & & & & $\mathbf{0 , 7 5 9 1}$ & 0,7527 \\
\hline Soy & & & & & $\mathbf{0 , 8 3 3}$
\end{tabular}

Source: Prepared by the author, 2020.

The values of the main diagonals, highlighted in bold, correspond to the result of the DFA, method that considers the autocorrelation. The values presented in the upper triangular matrix, without highlighting, correspond to the result of the DCCA, method that considers the 
cross-correlation. In order to figure the value of the cross-correlation between two companies, it is necessary to find the corresponding row and column. For example, the DFA value for sugar (second product in the table) is in the second row and second column; the DCCA value between sugar (second product) and coffee (third product) is in the second row and third column of the matrix.

At first, one notices that the values presented in the table are greater than 0.5 , which evidences the persistence characteristic of both DFA and DCCA, that is, as presented in item 2.4, large (or small) fluctuations are followed by fluctuations that behave in the same direction and intensity. Figure 6 presents the data distribution by means of a Boxplot graph.

Figure 6 - Boxplot of general results.

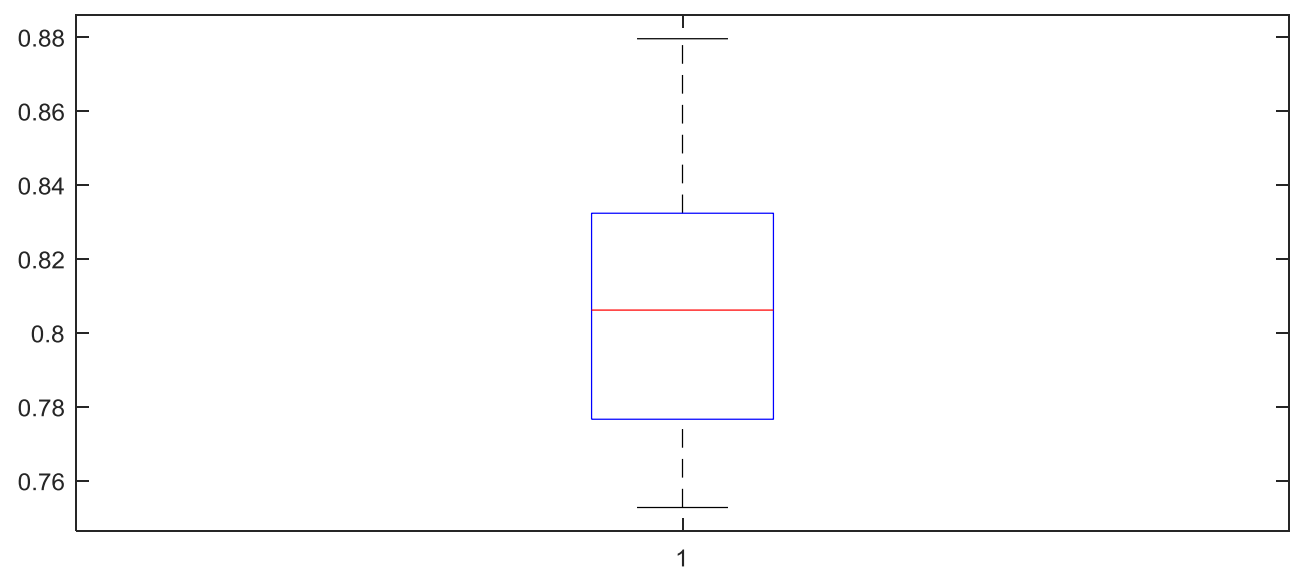

Source: Prepared by the author, 2020.

Coffee presents higher DCCA values (considering any other product in the crosscorrelation) compared to its DFA value, that is, the coffee return series has a more consistent correlation with the series of the other products when compared with its own return.

After checking the overall data, the series was divided into smaller time windows to analyze the differences in the correlation spectrum in periods before, during, and after the subprime crisis.

As shown in Table 2, for the pre-crisis period, the results for all products show values greater than 0.6 for the DFA and values greater than 0.7 for the DCCA. However, the average value for the DFA is approximately 0.73 , and for the DCCA, 0.79 , few values above 0.85 and none above 0.9 . 
Table 2 - DFA and DCCA results before the subprime crisis.

\begin{tabular}{c|c|c|c|c|c} 
& Cotton & Sugar & Coffee & Corn & Soy \\
\hline Cotton & $\mathbf{0 , 7 5 0 4}$ & 0,7365 & 0,8602 & 0,7384 & 0,7999 \\
\hline Sugar & & $\mathbf{0 , 7 5 5 9}$ & 0,868 & 0,7082 & 0,7997 \\
\hline Coffee & & & $\mathbf{0 , 7 1 7 3}$ & 0,8851 & 0,8669 \\
\hline Corn & & & & $\mathbf{0 , 6 9 7}$ & 0,728 \\
\hline Soy & & & & & $\mathbf{0 , 7 7 8 1}$
\end{tabular}

Source: Prepared by the author, 2020.

Table 3 shows the period of the subprime crisis, where it is possible to see that there is an increase in autocorrelation and cross-correlation when compared to the period before the crisis. With an average of 0.83 for DFA and 0.84 for DCCA, $93.3 \%$ of the products start from 0.8 . And the autocorrelation value for cotton, reaches more than 0.9 .

Table 3 - DFA and DCCA results during the subprime crisis.

\begin{tabular}{c|c|c|c|c|c} 
& Cotton & Sugar & Coffee & Corn & Soy \\
\hline Cotton & $\mathbf{0 , 9 1 1 7}$ & 0,8671 & 0,872 & 0,8646 & 0,872 \\
\hline Sugar & & $\mathbf{0 , 8 4 2 9}$ & 0,8511 & 0,844 & 0,8453 \\
\hline Coffee & & & $\mathbf{0 , 8 0 5 8}$ & 0,8026 & 0,7835 \\
\hline Corn & & & & $\mathbf{0 , 8 4 2 9}$ & 0,8452 \\
\hline Soy & & & & & $\mathbf{0 , 8 2 8 8}$
\end{tabular}

Source: Prepared by the author, 2020.

After the crisis, the autocorrelation and cross-correlation values decrease, becoming lower than those of the pre-crisis period; with an average of 0.70 for the DFA and 0.78 for the 
DCCA, minimum values of 0.67 and maximum of 0.88 , none exceeding the value of 0.9 , as presented in Table 4.

Table 4 - DFA and DCCA results after the subprime crisis.

\begin{tabular}{c|c|c|c|c|c} 
& Cotton & Sugar & Coffee & Corn & Soy \\
\hline Cotton & $\mathbf{0 , 7 8 2 9}$ & 0,7704 & 0,8882 & 0,8024 & 0,7629 \\
\hline Sugar & & & & & \\
\hline Coffee & & $\mathbf{0 , 7 2 7 2}$ & 0,8735 & 0,7238 & 0,6884 \\
\hline Corn & & & $\mathbf{0 , 7 5 2 6}$ & 0,7791 & 0,8258 \\
\hline Soy & & & & & 0,7579 \\
\hline
\end{tabular}

Source: Prepared by the author, 2020.

\section{DISCUSSIONS}

Comparing the pre-crisis autocorrelation coefficients with those that occurred during the crisis, it is observed that during the crisis all of the coefficients presented an increase in value. The same occurs if the comparison is made between the post-crisis coefficients and those that occurred during the crisis - all the coefficients during the crisis are larger than those of the post-crisis period.

Analyzing the pre-crisis autocorrelation coefficients with the post-crisis data, we observe that while sugar, corn and soy present slightly higher DFA prior to the crisis, cotton and coffee present slightly higher DFA in the post-crisis period. But the general behavior is a process of generalized increase of DFA in the crisis period and the return of DFA values, in the post-crisis period, to the levels existing in the pre-crisis period, as a compression/relaxation effect.

When comparing the cross-correlation coefficients of the pre-crisis periods with those of the crisis, we can observe that in $70 \%$ of the cases, there was an increase in the DCCA. In $20 \%$ of the cases there was a decrease in the crisis correlation coefficient: COFFEE-COAL 
AND COFFEE-SOYBEAN. We can consider a constant behavior in only one case, COFFEESUGAR, since the decrease was inexpressive.

The same comparison can be made between the coefficients observed in the post-crisis period in relation to the crisis period. Thus, we have that in $70 \%$ of the cases, the value of the DCCA during the crisis is higher than those verified in the post-crisis period. Only the following cases $(3$ cases $=30 \%$ ) present a correlation coefficient with opposite behavior: COFFEE-COTTON, COFFEE-SUGAR and COFFEE-SOYBEAN.

Table 5 - Comparison of the cross-correlation spectra for the different periods.

\begin{tabular}{c|c|c|c} 
& Before the Crisis & During the Crisis & After the Crisis \\
\hline Average & 0,799 & 0,845 & 0,787 \\
\hline Standard Deviation & 0,068 & 0,030 & 0,062 \\
\hline Kurtosis & $-1,628$ & $-0,035$ & $-0,754$
\end{tabular}

Source: Prepared by the author, 2020.

Analyzing Table 5, where the comparatives of the correction spectra for the different periods are presented, it is possible to notice that during a crisis period, the medium is $5.8 \%$ higher than in pre-crisis and $7.4 \%$ higher than in post-crisis. The dispersion measures are smaller during the crisis period: $56.18 \%$ smaller compared to the pre-crisis period and $52.30 \%$ compared to the post-crisis period. Analyzing the kurtosis data, notice that the DCCA distribution is platykurtic in the three periods, but with different intensities, and the highest kurtosis value occurs in the crisis period, that is, the correlations distribution is closer to a Gaussian in this period, since the kurtosis is practically null.

Table 6 - Comparison of the autocorrelation spectra for the different periods.

\begin{tabular}{c|c|c|c} 
& Before the Crisis & During the Crisis & After the Crisis \\
\hline Average & 0,740 & 0,846 & 0,723 \\
\hline Standard Deviation & 0,032 & 0,040 & 0,047 \\
\hline Kurtosis & $-1,327$ & $-0,312$ & $-1,521$
\end{tabular}

Source: Prepared by the author, 2020 .

Using Table 6, it is possible to perform the same analysis for the average values of the DFA, as in the crisis period, the average is $14.3 \%$ higher if compared to the period before the crisis and $17 \%$ higher if compared to the later period. The dispersion of the autocorrelation values has an increasing trend over time and the kurtosis of the distribution of the DFA values 
in the different periods is platykurtic, and as it occurred in the DCCA, the crisis period is when the highest kurtosis value is observed.

\section{CONCLUSIONS}

The researched products always present cross-correlations above 0.6, which indicates a persistent long term non-linear correlation, according to the behavioral limits detailed in item 2.4. Among the main contributions of the article, we can highlight the following: the calculations that allow us to observe, both for values (on average) of the DCCA, as well as the DFA, a movement similar to that of a spring when away from its equilibrium state, that is, the periods before and after the crisis correspond to the equilibrium state and the crisis period corresponds to the application of a force acting, in this case, to raise the cross-correlation between the products. Thus, what we obtained was a generalized increase in correlation in the crisis period. Subsequently, a return, on average, of the correlation values to pre-crisis levels. These long-term nonlinear correlation measures, however, are not homogeneous and we can highlight the individual behavior of some products, either because they have high or low correlation values. This allows us to use the idea of risk dilution through product portfolio formation. Coffee, for example, presented the lowest cross-correlation value, on average, at the time of the crisis, with a value of 0.8273 . Therefore, it is the product among those studied that would be ideal in the portfolio that is seeking to minimize risk. It was also possible to verify that the crisis altered the product with the highest DFA value among those analyzed and that the products with the lowest cross correlation are altered during the crisis.

The autocorrelation, measured by the DFA, presents an average in relation to the behavior of the DCCA, however the dispersion of the DFA values is increasing throughout time.

In individual terms, the behavior of the coffee product draws attention, since it is the only one whose DFA value is significantly lower than the DCCA values (considering the cross-correlation with any of the other products). This means that the price of coffee is less important in the past than the price of the other products analyzed to consider a long-term trend for the return value of coffee itself.

In general terms, soybean is the product that presented the highest autocorrelation value. However, despite this characteristic being present before the crisis, in the subsequent periods it is cotton that presents the highest DFA. Thus, there is a change in the product that 
presents the highest DFA in the crisis period, and this remains after the crisis. This inertia effect also happens with the highest DCCA values. If we consider the less correlated products, we have corn and sugar, both before and after the crisis. However, during the crisis, the lowest DFA value is between soy and coffee.

\section{References}

ABE, M. M. A Crise de 2008 e Seu Impacto em Países Economicamente Dependentes de commodities. 38 f. Dissertação (Mestrado em Economia) - Curso de Economia, Fundação Getúlio Vargas, São Paulo, 2011.

CARVALHO, F. C. Entendendo a Recente Crise Financeira Global. 2008. Disponível em: http://docplayer.com.br/11990329-Entendendo-a-recente-crise-financeira-global.html. Acesso em: 20 dez. 2018.

CEPEA. 2018. Disponível em: https://cepea.esalq.usp.br/br. Acesso em: 18 abr. 2018.

CREPALDI, A.F. Abordagem de Modelos Baseados em Agentes no Estudo de Séries Temporais Financeiras. Tese. (Doutorado em Física) - Universidade Estadual Paulista Júlio de Mesquita Filho, UNESP, São Paulo, 2007. Disponível em: http://www.dominiopublico.gov.br/pesquisa/DetalheObraForm.do?select_action=\&co_obra=1 52819. Acesso em 20 dez 2018.

EHLERS, R. S. Análise de séries temporais. Curitiba: Laboratório de Estatística e Geoinformação, Universidade Federal do Paraná, 2007. Disponível em: http://www.icmc.usp.br/ ehlers/stemp/stemp.pdf.. Acesso em 20 dez 2018.

EMBRAPA SOJA. Soja em Números (Safra 2019/2020). Disponível em <https://www.embrapa.br/soja/cultivos/soja1/dados-economicos $\geq$ Acesso em: 06 abr. 2021.

GEMAN, H. Commodities and commodity derivatives: modeling and pricing for agriculturals, metals and energy. Wiley, 2005.

GUTH, T. L. F. Análise Mensal. Milho (junho/julho de 2019). CONAB. Disponível em $<$ https://www.conab.gov.br/info-agro/analises-do-mercadoagropecuarioeextrativista/analisesdo-mercado/historico-mensal-de-milho.> Acesso em: 06 abr. 2021.

JALE, J. da S. Commodities agrícolas do agronegócio brasileiro: análise multifractal e análise da complexidade diante da crise financeira mundial subprime 2008/2009. 2015. 156 f. Tese (Programa de Pós-Graduação em Biometria e Estatística Aplicada) - Universidade Federal Rural de Pernambuco, Recife.

KOSCIELNY-BUNDE, E.; BUNDE, A.; HAVLIN, S.; ROMAN, H. E. Indication of a universal persistence law governing atmospheric variability. Physical Review Letters, v. 81, n. 3, p. 729, 1998 .

KRISTOUFEK, L. Measuring cross-correlation between non-stationary series with DCCA coefficient. Physica A, v. 402, p. 291-298, 2014.

MARINHO, E. B. S., SOUSA, A. M. Y. R., ANDRADE, R. F. S. Using Detrended CrossCorrelation Analysis in Geophysical Data, Physica A, v. 392, p. 2195-220, 2013. 
MINISTÉRIO DA AGRICULTURA. Balança Comercial - Série Histórica (1997-2017). $2017 . \quad$ Disponível em: <http://www.agricultura.gov.br/assuntos/relacoesinternacionais/estatisticas-de-comercio-exterior> Acesso em: 20 dez. 2018.

MORETTIN, P.A.; TOLOI, C.M.C. Análise de Séries Temporais, ABE - Projeto Fisher. Editora Edgard Blucher LTDA, São Paulo, 2004.

PENG, C.-K. et al. Quantification of scaling exponents and crossover phenomena in nonstationary heartbeat time series. Chaos: An Interdisciplinary Journal of Nonlinear Science, v. 5, n. 1, p. 82-87, 1995.

PENG, C.K. HAVILIN, S., STANLEY, H.E., GOLDBERGER, A.L. On the mosaic organization of DNA sequences. Physical Review E, n. 49, p. 1685-1689, 1994.

PODOBNIK, B., STANLEY H.E, Detrended cross- correlation analysis: A new method for analyzing two non-stationary time series. Physical Review Let, v. 100, p .084102, 2008.

PODOBNIK, B.; JIANG, Z.Q.; ZHOU, W.X.; STANLEY H.E. Statistical tests for power-law cross-correlated processes. Physical Review E, v. 84, p. 066118, 2011.

SEVERINO, L S et al. Série Desafios do agronegócio Brasileiro (NT3). Produto: Algodão - Parte 01: Caracterização e Desafios Tecnológicos. EMBRAPA, 2019. Disponível em: $<$ https://ainfo.cnptia.embrapa.br/digital/bitstream/item/198192/1/SerieDesafiosAgronegocioB rasileiroNT3Algodao.pdf.> Acesso em: 06 jan. 2021.

SHAHBANDEH, M. Global sugar production by leading conuntry 2019/2020.

STATISTA, 2019. Disponível em: <https://www.statista.com/statistics/495973/sugarproduction-

worldwide/\#: :text=This\%20statistic\%20shows\%20the\%20sugar,million\%20metric\%20tons \%20of\%20sugar $\geq$ Acesso em: 06 jan. 2021.

SILVA FILHO, A. Correlação de Longo Alcance em Indicadores de Criminalidade de Salvador - BA: DFA E DCCA. Dissertação. 2009. 120f. (Mestrado) -. Faculdade de Tecnologia Senai Cimatec, Salvador, 2009.

SILVA, D. R. C. Utilização do Dentreded Fluctuation Analysis e do Dentreded CrossCorrelation Analysis para estudo do espectro de correlação de ações constantes no Ibovespa no período de crise do subprime . 2017. 88 f. Dissertação (Mestrado) - Curso de Engenharia de Produção, Universidade Estadual Paulista, Unesp, Bauru, 2017.

SIQUEIRA JÚNIOR, E.L.; BEJAN, L.B.; STOSIC, T. Comparando produtos agropecuários e ações no mercado brasileiro usando Detrended Fluctuation Analysis em séries históricas de preços. In: ENCONTRO REGIONAL DE MATEMÁTICA APLICADA E COMPUTACIONAL, 7, 2008. Anais... Natal, 2008.

SIQUEIRA JÚNIOR, E.L.; STOSIC, T.; BEJAN, L.B. Correlations and cross-correlation in the brazilian agrarian commodities and stocks. Physica A, n. 14, v. 389, p. 2739-2743, 2010.

UNITED STATES DEPARTAMENT OF AGRICULTURE (USDA). Coffee: World Markets and Trade. 2019/2020 forecast review, 2019. Disponível em: $<$ https://downloads.usda.library.cornell.edu/usdaesmis/files/m900nt40f/sq87c919h/8w32rm91 m/coffee.pdf.> Acesso em: 06 jan. 2021. 
URSULEAN, R; LAZAR, A.M. Detrended Cross-Correlation Analysis of Biometric Signals used in a new Authentication Method. In: THE INTERNATIONAL CONFERENCE ELECTRONICS AND ELECTRICAL ENGINEERING, 13 ${ }^{\mathrm{TH}}$. Anais...Lithuania, 2009.

WANG, G.; XIE, C.; CHEN, S.; YANG, J.; YANG, M.J.W. Random matrix theory analysis of cross-correlations in the US stock market: Evidence from Pearson's correlation coefficient and detrended cross-correlation coefficient. Physica A, n.17, v. 392, p. 3715-3730, 2013. 